\section{SOI: $\underline{1.1 / \mathrm{TAS}}$ DOI: $\underline{10.15863 / \mathrm{TAS}}$ \\ International Scientific Journal Theoretical \& Applied Science}

p-ISSN: 2308-4944 (print) $\quad$ e-ISSN: 2409-0085 (online)

Year: 2015 Issue: 03 Volume: 23

Published: $30.03 .2015 \quad$ http://T-Science.org
Shakhnoza Yunusova

Teacher of

Tashkent State Pedagogical University

Tashkent, Uzbekistan

shakhnozayunusova@mail.ru

SECTION 29. Literature. Folklore. Translation

Studies.

\title{
ON ADVERTISEMENT LEXIS. SLOGAN BASED RESEARCH
}

Abstract: The article deals with the on advertisement lexis of in the Uzbek language. And also analyzed the slogans formation of methods in language.

Key words: advertisement, advertisement texture, advertising, advertisement lexis.

Language: English

Citation: Yunusova S (2015) ON ADVERTISEMENT LEXIS. SLOGAN BASED RESEARCH. ISJ Theoretical \& Applied Science 03 (23): 69-71.

Soi: http://s-o-i.org/1.1/TAS*03(23)14 Doi: crossef http://dx.doi.org/10.15863/TAS.2015.03.23.14

Uzbek advertisement - is a sphere of rapid development, while its rules are merely being studied. Time and researches indicate that advertisement appears to push not only trade, but spurs speech development as well.

The role of advertisement in nowadays life - in terms of market economy is very important.

Advertisement is such a process, it can be encountered every day and any place. Advertisement penetrates into all the spheres of public mass communication. Basing on mass media, one can segregate 5 vital types of advertisement, such as: 1 . Press advertising. 2. Radio advertising. 3. Television advertising. 4. External advertising. 5. Internet advertising and etc.

Please compare:

Evo - tezlikni his et.

(Evo - experience the speed)

Evo bilan butun olamingni o`zgartir.

Change your whole world with Evo.

What is slogan? Slogan being the most important element of advertisement, is alike a telegram. Having seen the slogan, society members decide whether to read the rest of the advertisement texture [4, p. 31].

According to R.Reaves, Advertising Specialist, a consumer memorizes a precise definition either a
Advertisement implements a row of tasks in the society. Important ones are: 1. Advertisement is subject to provide information. 2. Advertisement is subject to convince [1, p. 13].

Information providing texture can be divided into the following parts.

1. Ktematonym (gr. ktemo «property» + onima «name») - word expression of a trade mark.

2. Slogan (Engl. slogan «logo») - short slogan expressing good advertisement. It is to be short, precise and easy-to-remember.

3. The task of ktematonym or any good being advertised - is to express the idea and context in short, precise and imaginative shape. This process can be provided by one or two phrases [5, p. 158].

(slogan)

Ktematonym (evo) - bilan butun olamingni (your whole world)

o`zgartir (change) - (characterizing phrase)

definite idea from the advertisement [3, p. .27]. He had made a slogan for M\&M's chocolates. Please compare: «Tayut vo rtu, a ne v rukah» (Melts in your mouth, nor in your hand). It is obvious that chooses the most important feature of the chocolate as its slogan, i.e., it does not melt in hands due to julep burled surface. 
Generally, slogan is a short imaginative means, aphorism. Slogans are used in any types of advertisements. The basics of slogans are those words, instantly effecting human psychology. Please compare: yangi, bepul, hayot, samarali, tabiiy, arzon.. (new, free of cost, life, fruitful, natural, of low cost)...

Happiness, welfare life, dreams coming true are usually promised and expressed in slogans. As basics of an advertisement concept, a slogan accumulates in itself the following:

- Action persuasion: Uzdunrobita kompaniyasiga a'zo buling! (Join Uzdunrobita company) Premyer taksiga a'zo bul! (Join PremierTaxi). Chegirmalar mavsumi boshlandi! (Sales season started). Aloqani mustaqil boshqar! (Control communication independently). Darakchiga obuna buling va yuting! (Subscribe for Darakchi and gain)

- evaluation of enterprise advertising the good: Aziza Ziyo orzular ruyobi (Aziza Ziyo implementation of dreams) (about education centre). Bu erda hamma narsa bor (There is everything here) (about supermarket). Infomed yagona tibbiy ma'lumotlar hizamati (Infomed - one medical information service). groups:

As per their shape Slogans can be divided into 3

1. Associate slogan. Name of a good is mentioned in associate slogan.

Har doim Coca-Cola! ( Always Coca-cola).

2. Harmonized slogan. In the harmonized group slogan comes in phonetic and rhythmic harmony with a good being advertised. Alumaq - oshqozonga kumak; Ermak - bu foydali, mazali va demak; Muza bilan siz, betakror pazandasiz.

3. Random (free) slogan. Trade mark is used separately in random slogan.

Nescafe. Hammasi yahshilikka. (Everything is for good). Nestle. Musaffo hayot davri keldi (Time to live a clear life)!

Shaffof. Birinchi buloq suvi! (First well-water). Coca-Cola. Hayot lazati (Taste of life).

Slogans do express a main idea of an advertisement. Basically, they combine the following concepts and meanings: 1.Olg'a! (En avant!) Attraction of attention towards good by means of conviction. 2. Chegirmalar mavsumi boshlandi! (Sales season started!) - convoke. 3. Sotib oling! Iching va rohatlaning (Purchase! Drink and enjoy!) (SIBUR)

Emotionally colorful phrases of a positive opinion do provide an idea of enjoyment of a good being advertised. For example, aged man and woman are sitting on the seat in the video of a Lottery advertisement. Man gives a lottery ticket to the woman and the following slogan appears on the screen. Sevgi yosh tanlamaydi (Love all ages yield surrender).

Sometimes concept, contents of a slogan do not match with a good being advertised. Slogan is usually provided by comparison. Uzing hal qil, chanqog'ingga ishon! Sprite! (Obey your thirst! Sprite!) slogans.

The following methods are used in formation of

1. Metaphor (gr.metaphora - transfer). If an object, sign, action is referred in similarity with other - it is then called as reference in metaphoric method. Metaphor is one of the main elements in formation of new concepts of a word. Slogans created in metaphoric method are many. Please compare: PANTERRA STUDIO - Uzbekiston yulduzlari mehmoningiz buladi! (Stars of Uzbekistan will be your guests!)

2. Lexical reiteration. Reiteration of a word or word combination does provide emotionality and impressiveness to a speech. Please compare:

\section{Coca-Cola hursand buling hayordan, hayotdan bahra oling! \\ Coca-cola. Enjoy life, delight with life!}

3. Epiphora (gr.epiphora<epi-then+phoroscoming). Epiphora is reiteration of an exact element in the end of phrases (f.e. Distiches) shaped in parallel method of creation [5.134].

Oddiy emas - $\underline{\text { toza }}$,

nuqsonsiz toza («Ariel» powder detergent).

«Birinchi sumli» tariff rejasi.

Bu milliy valyutadagi birinchi tariff rejasi.

4. Anaphora (gr. anaphora - elevation upwards). Anaphora is reiteration of an exact element in the beginning of phrases (f.e. Distiches) shaped in parallel method of creation [2, p. 14].

\section{Sizning raqamingiz -}

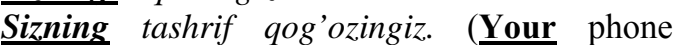
number is your visiting card).

Unitilmas kunlarda a'lo.

$\underline{\text { Unitilmas }}$ ta'm «Tuhtaniyoz - Ota» hammadan

(Unforgettable taste in unforgettable days "Tuhtanoyoz-Ota" - best among all).

Slake yangi hayot

yangi ta'm. (Slake - new life, new taste).

Credit Standart Bank yangi standartlar 
yangi imkoniyatlar.

(Credit Standart Bank - $\underline{\text { new }}$ standards, $\underline{\text { new }}$ opportunities).

The conclusion is - that formation, creation of slogan is considered to be a peculiar complicated logical process. Successful, impressive slogans created in this process are not just combination of effective, visually attractive words, but are the outcome of fruitful efforts, result of today's requirements and one of unique linguistic expressions of market economy.

\section{References:}

1. Farbi ED (2004) Kak sozdat uspeshnuyu reklamu (How to make a successful advertisement).-S.P b., 2004.

2. Hojiev A (2002) Tilshunoslik terminlarning izohli lugati. (Explanatory dictionary of linguistic terms). -T., 2002.

3. Medvedeva EV (2003) Reklamnaya propaganda, ili «pochem opium dlya naroda?» (Advertisement propaganda or "how much is the opium for public?” MSU Bulletin. Issue.19. №1. 2003.

4. Nesterenko FP, Babadjanova GN (2003) Effektivnaya rekalama (Effective advertisement). -T., 2003.

5. (2004) Stilistika. I literaturnoe redaktirovaniye. (Stylistics and literal editing). Under edition of Prof.V.I.Maksimov. - Moscow, 2004.
6. Apresyan YD (1974) Leksicheskaya semantika. - Moscow: Nauka,1974.

7. Dobrobabenko NS (2004) Reklamnye teksty bogaty boykost'yu. Reklama. - 2004, №4.

8. Kara-Murza ES (2015) Ruskiy yazyk v reklame. Spravochno-informatsionnyy portal "Russkiy yazyk". Available: http://www.gramota.ru (Accessed: 7.03.2015).

9. Lutts I (1999) Rozhdeniya slogana. Reklamnye tekhnologii. 1999 - №4.

10. Medvedeva EV (2003) reklamnaya propoganda, ili pochem opium dlya naroda? Vestnik MGU Seriya 19, Lingvistika i mezhkul'turnaya kommunikatsiya. 2003, №1. 